\title{
CONCEPT OF UNCERTAINTY IN RELATION TO THE FORESIGHT RESEARCH
}

\author{
ANDRZEJ MAGRUK
}

\begin{abstract}
A B S T R A C T
Uncertainty is one of the most important features of many areas of social and economic life, especially in the forward-looking context. On the one hand, the degree of uncertainty is associated with the objective essence of randomness of the phenomenon, and on the other, with the subjective perspective of a man. Futureoriented perception of human activities is laden with an incomplete specificity of the analysed phenomena, their volatility, and lack of continuity. A man is unable to determine, with complete certainty, the further course of these phenomena. According to the author of this article, in order to significantly reduce the uncertainty while making strategic decisions in a complex environment, we should focus our actions on the future through systemic research of foresight. This article attempts to answer the following research questions: 1 ) What is the relationship between foresight studies in the system perspective to studies of the uncertainty? 2) What classes of foresight methods enable the research of uncertainty in the process of system inquiry of the future? This study conducted deductive reasoning based on the results of the analysis methods and criticism of literature.
\end{abstract}

KEY W ORDS

uncertainty, foresight, future, system, determinism

DOI: 10.1515/emj-2017-0005
Corresponding author:

Andrzej Magruk

Bialystok University of Technology, Management Faculty, International China and Central-Eastern Europe Institute of Logistics and Service Science, Poland

e-mail: a.magruk@pb.edu.pl

\section{INTRODUCTION}

In all spheres of human activity, uncertainty plays a special role. In the economic context, it is recognized as one of the major global megatrends alongside such phenomena as circular economy \& sustainability, regional empowerment, collaborative crowd economy, and volatility (Bubner et al., 2014). Uncertainty is inherent in any decision. This is because the essen- tial feature of the decision-making process is the orientation towards the future, which is inherently uncertain (Dziel, 2011).

The high pace of change in the social, economic, and technological areas and high complexity of the today's world functioning led to an increasing need to manage these changes and the accompanying uncertainty to create wealth and enhance the quality of life 


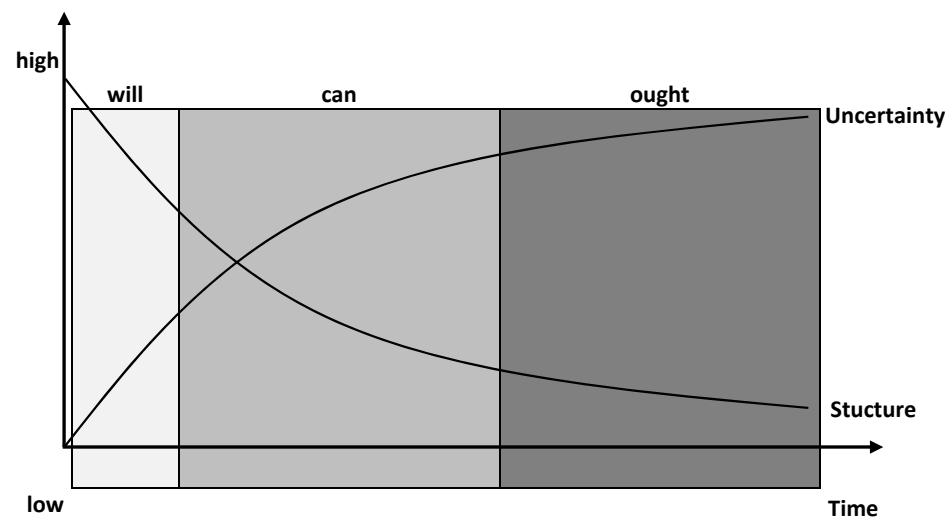

foresight studies in the system perspective to studies of the uncertainty? 2) What classes of foresight methods enable the research of uncertainty in the process of system inquiry of the future? This study conducted deductive reasoning based on the results of the analysis methods and criticism of literature.

Fig. 1. Structure and uncertainty relationship

Source: (Saritas \& Oner, 2004 redrawn from Graf, 1999).

by taking the relevant decisions (Saritas \& Oner, 2004).

In our daily lives, some answers to some problems are so simple that we are not even aware of their making and execution. However, extending of the time horizon increases the feeling of uncertainty regarding the ability to make based on known patterns. The number of components of the problem increases by getting lower awareness of the types and characteristics of the components of these problems (Fig. 1), (Saritas \& Oner, 2004).

If a decision problem is more complex, it is more difficult to recognize its essence and take appropriate action. It is impossible to specify both the effects, circumstances and conditions, in which these activities are exercised. There are situations where it is impossible to predict what consequences will be decided. Such situations are situations of uncertainty. It is impossible to predict the consequences, but it is possible to anticipate different variants of these effects (Euczak, 2012). According to the author of this article, the methodology of systemic research of foresight is one of the major approaches that allow this action. It is also one of the most powerful tools that help to build a clear "cone of future possibilities" by minimizing the uncertainty effect.

Each systemic object can be treated as a huge, multi-level structure. The study of such systems always contains a barrier of the uncertainty resulting from the barriers of unawareness about the system. The source of this ignorance may be either the incomplete information available on the audited system or limited cognitive abilities of a researcher. It is not possible to eliminate this barrier (Bojarski, 1981).

This article attempts to answer the following research questions: 1) What is the relationship between

\section{CONCEPT OF THE SYSTEM AND THE DETERMINISM TOWARDS THE PHENOMENON OF UNCERTAINTY}

According to Skolimowski, nature has been written in the language of the entirety. The wholeness is not only a term used to describe the relationship between the parts but is also an epistemological category: the total and holistic thinking are ways to understanding all aspects of starting from a single man and ending with the universe. We live in an open non-deterministic world. We should realize that the world is ruled by a variety of subtle dependencies that have nothing to do with the determinism understood in the positivist way (Błajet, 2011).

At the beginning of the nineteenth century, Pierre Simon, Marquis de Laplace, under the influence of successful scientific theories, put a bold but as it turned out - after about a hundred years - irrelevant hypothesis that the universe is completely determined. According to this approach, knowing the exact state of all phenomena in a given moment, a man could predict the exact state of this phenomena in the future, including human behaviour. Laplace's doctrine remained the classical assumption in science until the early years of the twentieth century. A milestone in breaking this position was the indeterminacy (uncertainty) principle in quantum physics formulated by Heisenberg in 1926 . This principle, using largely the assumptions of probability, is considered to be a fundamental property of the world inevitable. The indeterminacy principle, resulting from the uncertainty of measurement, introduced to the science the attitude of paying attention to the phenomena of randomness and unpredictability. This means that it is not really possible to accurately predict future events if we are not able to determine, with 
sufficient precision, the current state of the universe (Hawking, 1990). The theory of heat was another important theory that came from the field of statistical mechanics, preceding the indeterminacy principle (the last decades of the nineteenth century), which began to follow the scientific thinking towards indeterminism. One of the most important scientists working on this topic was Maxwell. He used the concept of singularities referred to as small disturbances of occasion causing large disturbances in the effects (Heller, 2016b).

Indeterminacy compounds define the limit, beyond which it is impossible to move the concepts of classical physics. Similarly, it can be said that the level of complexity (and, thus, also the uncertainty) of the system marks the boundary, beyond which it is impossible to examine the system following the principles of deterministic relationships.

In the early 60 s of the twentieth century, Zieleniewski pointed out that the study of whole states cannot accurately observe all the characteristics of the elements of the structure and at the same time changes in this structure. This brings up the principle of indeterminacy of large dynamic systems. It involves the inability to freely and accurately determine, in any narrow range of time, all states of elements and their relationships in a big system in the past, and even more so in the future. Perforce, therefore, abstract static tests of selected attributes and their relations are used or dynamic tests of changes some few traits without the other (Bojarski, 1981). This can be used, for example, in the principle of economy known as Ockham's razor, by removing from the theory everything that cannot be observed (Fatyga, 2015).

The uncertainty in the context of the analysed system may include (Fig. 2), (Bojarski, 1981):

- $\quad$ one or more parameters of the system;

- the equation of state or system motion;
- the structure of the system;

- the internal and external scope of the system;

- the desirability of preserving the system.

For further horizons, uncertainty continues to expand and deepen. This is due to, among other things, the complexity of the features, structures, and behaviours of systems, which usually extends beyond the area observed and verified by available knowledge, especially for individuals. On the occurrence of uncertainty in the context of a forward-looking analysis of the complex systems development affect the following factors (Bojarski, 1981):

- a multitude of possible system structures, their high complexity, and variability over time;

- the number and strength of connections inside the system;

- the number and degree of knowledge of the system's relations with the environment, and insufficient knowledge of the environment;

- the scope of structural changes;

- behaviour of individuals and institutions managing system test in the context of the potential going beyond the known rules and regulations;

- ignorance of potential new rules and principles and their scope;

- an increasing number of possible combinations of events occurring in the studied systems;

- the length of the considered time horizon;

- the lack of sufficiently complete data.

Uncertainty next to the complexity of the studied phenomena (systems) creates a space, in which one can determine the boundaries of computability (Fig. 3).

Despite the fact that knowledge is the lifeblood of developing and developed economies (Olszewska \& Gudanowska, 2011), live systems, the climate, and the economy still require for fields to experiment and statement claims demand for necessary but uncertain prove (Cempel, 2005).

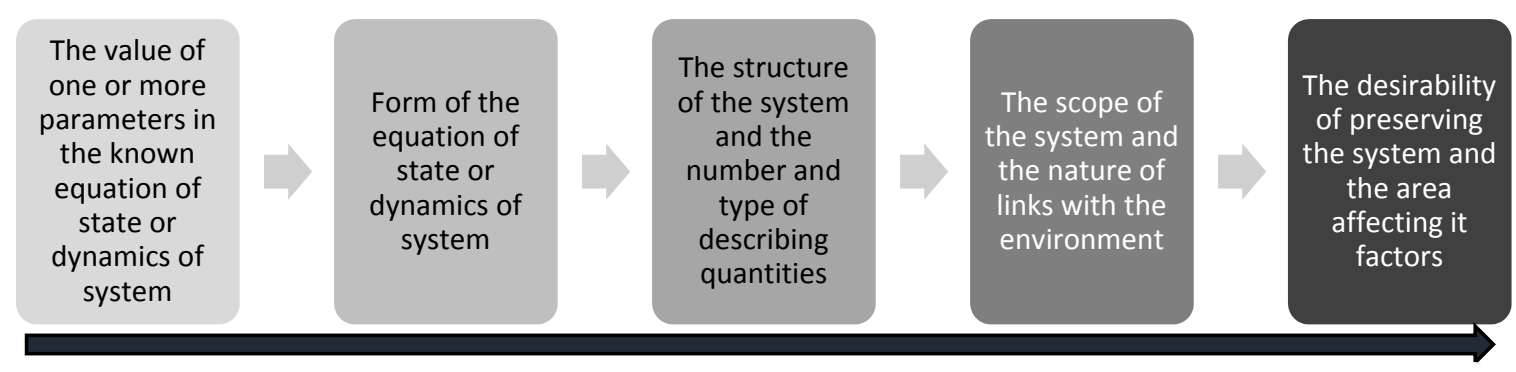

Low uncertainty range

High uncertainty range

Fig. 2. Level of the scope and significance of uncertainty in the context of the system

Source: own elaborations on the basis of (Bojarski, 1981). 


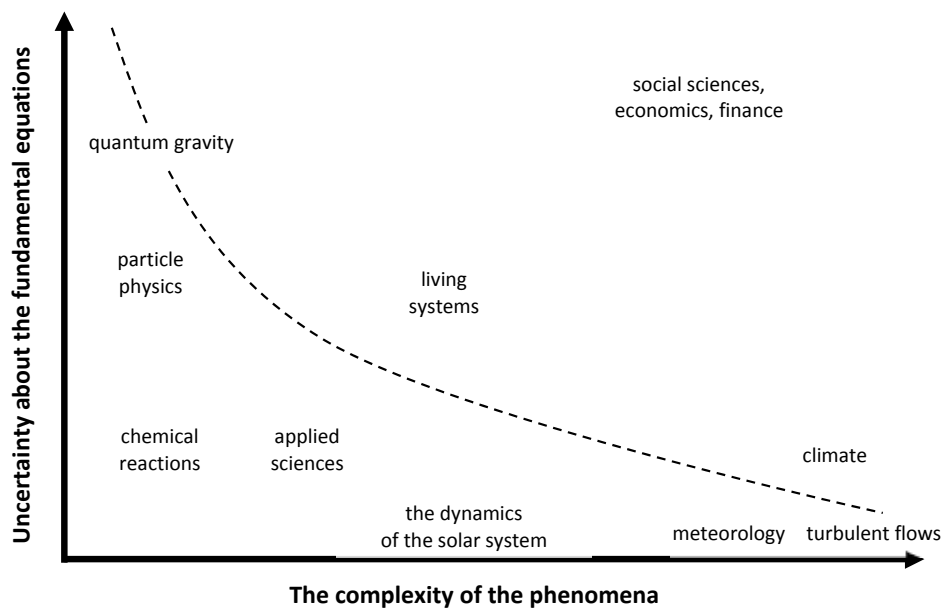

Fig. 3. Uncertainty and complexity as the boundaries of our knowledge Source: (Cempel, 2005).

\section{FORESIGHT RESEARCH IN RELATION TO THE CONCEPT OF UNCERTAINTY}

Expert (intuitive) research approaches can be used to determine the vision of the development of phenomena in time significantly exceeding the maximum horizon of typical forecasts (based on deterministic models), (Halicka, 2016; Halicka, 2014). One such tool is the methodology of foresight, based on the collective expertise anticipation of complex phenomena.

Especially complex foresight studies try to predict the uncertain future affected by many factors. In terms of the nature of the foresight process, uncertainties should always be taken into account (in addition to the complexity and conflictuality of nature). Incorrectly defined and unstructured problems reflect the higher dynamic complexity, and thus uncertainty. Foresight should be used to anticipate an uncertain future taking into account the numerous factors and complex structural and behavioural dependence (Saritas \& Oner, 2004).

Foresight is exploring the future through its impact on the present. So, we have to deal with the practical application of the reversal arrow of time, a well-known phenomenon in quantum physics (Błajet, 2011). Intuitively, future studies can consider only psychological variation of the arrow of time. It is linked to the human sense of the passage of time, the fact that we remember the past and not the future (Hawking, 1990). In the case of perception reversal, as may be in the foresight case, "we can remember" events from the future and try to play all the situations that preceded it, in the anti-chronological order. Thanks to this approach, it seems to be an easier implementation of one of the paramount roles of foresight - not foreseeing but understanding the future (Gudanowska, 2016) by creating it (Gudanowska, 2014).

In the process of inquiry into the future, there are two types of conditions on the anticipation and decision-making. Referring to the researches by Willett, these are the conditions of objective risks (mathematically quantifiable) and subjectively interpreted uncertainty (Janasz, 2009).

The conditions of risk exist when our every action leads to one outcome of a particular set of possible outcomes. Terms of uncertainty occurring then if one or both actions are a result of a set of defined possible outcomes (the set is not fully defined, we know some alternatives results but not all), but the probability of occurrence of these results is totally unknown or impossible to know (Fig. 4), (Samecki, 1967).

Uncertainty in foresight research is rather the background of its research and not its main subject. However, there are several methodological areas of foresight, in which the problem of uncertainty is the object of research, i.e.:

- scenario analysis;

- future cone;

- cone of uncertainty;

- strategic foresight.

The result of foresight research is usually a space of possible scenarios, which, according to Ringland may be defined as part of strategic actions, which relates to the tools and technologies for managing the uncertainties of the future (Ringland, 1998).

Mietzner and Reger claim that scenario planning allows us to understand the degree of uncertainty and its importance while scenario building means speculating about the future uncertainty (Kononiuk \& Nazarko, 2014).

Referring to research by Kononiuk and Nazarko, based on the concepts of Amara and Bazolda (Kononiuk \& Nazarko, 2014) and studies of Voros (Voros, 2003), probable, plausible, possible, preferable and desirable scenarios can be distinguished (Fig. 5).

The expanding cone shows the complexity and uncertainty of the future. This is because the farther 

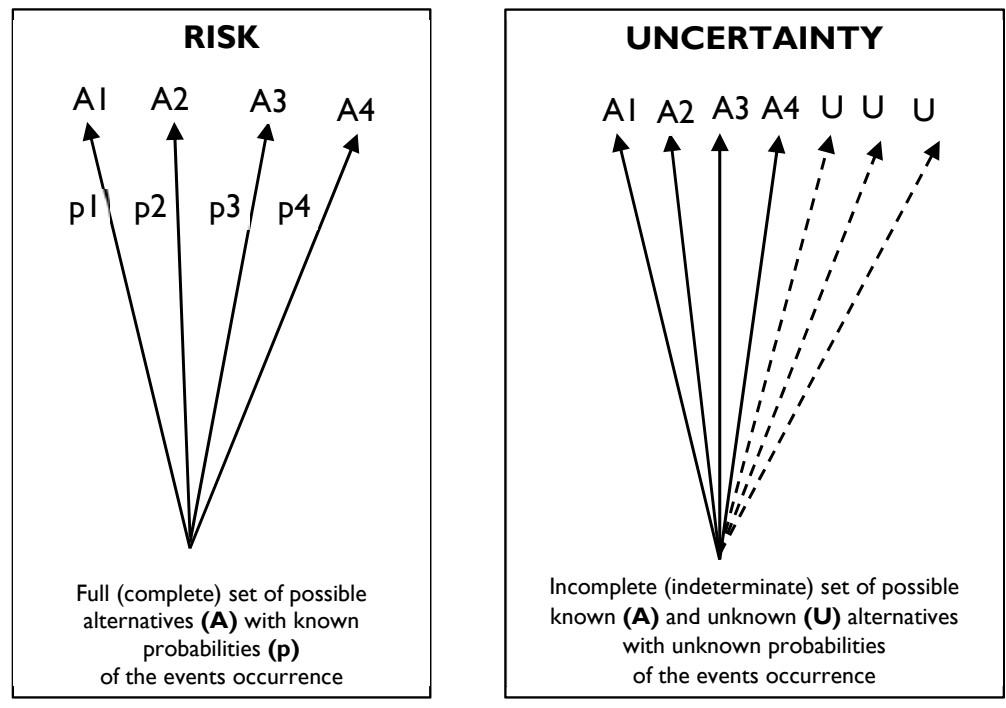

Fig. 4. Conditions of risk and uncertainty

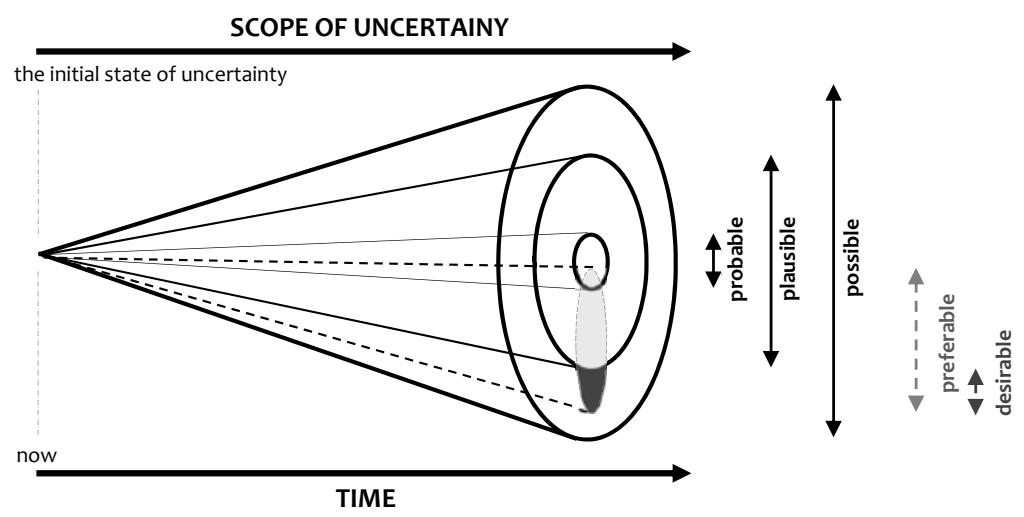

Fig. 5. Cone of future

Source: own elaborations on the basis of (Kononiuk \& Nazarko, 2014; Voros, 2003). we run out into the future, the further increases the scope of uncertainty. At the same time, increases the rate of change in the structure of the observed system (Błajet, 2011).

Another important area of future studies in the field of uncertainty is the cone of uncertainty and possibilities (Fig. 6). The archetype of these analyses in the form of a light cone of the future and the past is in spacetime research within the framework of special and general relativity theory (Hawking, 1990; Heller, 2016a).

Referring to studies by Hawking, the absolute future event $\mathrm{P}$ is inside the cone of the future. It is a collection of all events, which can affect what happens in $\mathrm{P}$. The absolute past events $\mathrm{P}$ is a region within the cone of the past. It is a collection of all these events, for which the information could get to $P$. Hence, the absolute past $\mathrm{P}$ is the set of all events that could have an impact on what happened in P. In the completely deterministic system,

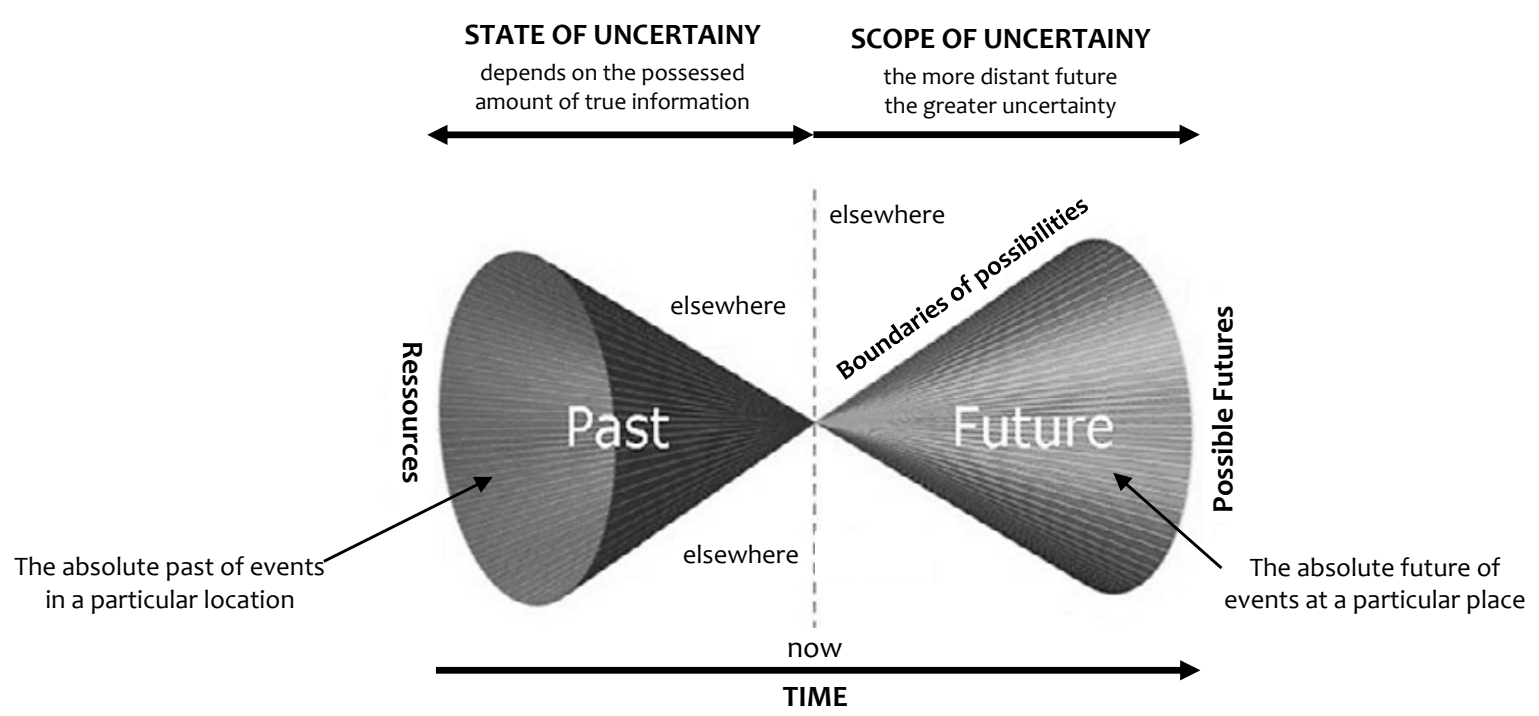

Fig. 6. Cone of uncertainty and possibilities

Source: own elaboration on the basis of (Hawking, 1990; Magnus, 2012). 
if it would be known what was happening at a specific time at all points of the space area situated within the cone of the past, it could be a possibility to predict with a high probability, what will happen in the $\mathrm{P}$ (in indeterministic systems, past and present events determine only distribution probabilities of possible states in the future (Heller, 2016b). "Elsewhere" is the part of the space lying outside the two cones of events $\mathrm{P}$. The events in the "elsewhere" cannot affect the P or the P incident cannot affect them (Hawking, 1990).

According to Magnus, the cone of uncertainty and possibilities is a model of all development roads in the future. It is conditioned by the resources of knowledge and information from past and present. More probable future's paths are closer to the centre, and unrealistic paths (by increasing the extent possible, while high uncertainty) are located on the outskirts of the cones (Magnus, 2012).

Residual uncertainty is characteristic of strategic foresight and is defined by Courtney as the uncertainty left after the best possible analysis to separate the unknown from the unknowable. The residual uncertainty always takes only one of four levels (Table. 1), (Courtney et al., 1997; Courtney, 2001):

- Level 1: A Clear-Enough Future;

- Level 2: Alternate Futures;

- Level 3: A Range of Futures;

- Level 4: True Ambiguity.

Another complementary approach is presented by Jańczuk. It distinguishes three types of uncertainty in the context of foresight: simple uncertainty (which is the difference between certainty and reliability in terms of risk), accumulated (uncertainty in the strict sense) and independent uncertainty (unprecedented). Independent uncertainty refers to abnormalities that represent a total surprise to the observer. Knowledge of these phenomena appears simultaneously with the occurrence of it (Jańczuk, 2007).

\section{CLASSES OF FORESIGHT METHODS INFLUENCING THE PROCESS OF UNCERTAINTY RESEARCH}

Because in the predictive considerations, one of the main aims is to minimize any uncertainties associated with predictions, the question is: "What foresight methods affect the identification and analysis as well as minimize the effects of uncertainty?". Due to the limited capacity of the article, the Tab. 2 below shows the answer in the accumulated form, based on the research relating to classes of foresight methods. Detailed description of the classes and methods belonging to them (Table 2) is provided by (Magruk, 2011).

Based on the analysis of the characteristics of individual foresight research methods and the author's experience resulting from active participation in several foresight initiatives, the total assessment of the relationship of classes of methods was made for testing the uncertainty in 3 aspects: identification, analysis and minimization (Table 3 ).

The first class is a consultative group of methods based on the study of expert opinion. This is particularly important in the case of complex issues where there is a high uncertainty regarding the interpretation of the data in the forward-looking context. Thanks to the methods of this cluster, it is possible to collect tacit knowledge, inaccessible in traditional

Tab. 1. Four levels of residual uncertainty

\begin{tabular}{|c|c|c|c|c|}
\hline & Level 1 & Level 2 & Level 3 & Level 4 \\
\hline Graph & & & & \\
\hline Definition & $\begin{array}{l}\text { Can be developed a single forecast of } \\
\text { the future that is precise enough for } \\
\text { strategy development }\end{array}$ & $\begin{array}{l}\text { The future can be described as one of } \\
\text { a few alternate outcomes, or discrete } \\
\text { scenarios }\end{array}$ & $\begin{array}{l}\text { Range of potential futures is defined } \\
\text { by a limited number of key variables }\end{array}$ & $\begin{array}{l}\text { Multiple dimensions of uncertainty } \\
\text { interact to create an environment } \\
\text { that is virtually impossible to predict }\end{array}$ \\
\hline Example methods & $\begin{array}{l}\text { market research, analyses of } \\
\text { competitors' costs and capacity, value } \\
\text { chain analysis, Porter's five-forces } \\
\text { framework }\end{array}$ & $\begin{array}{l}\text { decision analysis, option valuaion } \\
\text { models, game theory }\end{array}$ & $\begin{array}{l}\text { lantent-demand research, technology } \\
\text { forecasting, scenario planning }\end{array}$ & $\begin{array}{l}\text { analogies, pattern recognition, } \\
\text { nonlinear dynamic models }\end{array}$ \\
\hline
\end{tabular}

Source: (Courtney et al., 1997; Courtney, 2001). 
Tab. 2. Classification of foresight research methods

\begin{tabular}{|c|c|}
\hline $\begin{array}{l}\text { THE NAME OF } \\
\text { CLASSES }\end{array}$ & FORESIGHT METHODS BELONGING TO EACH CLASS \\
\hline Consultative & $\begin{array}{l}\text { Voting, Polling, Survey, Interviews, Expert Panels, Essays, Conferences, Workshops, Citizen Panels, } \\
\text { Brainstorming }\end{array}$ \\
\hline Creative & $\begin{array}{l}\text { Wild Cards, Weak Signals, Mindmapping, Lateral Thinking, Futures Wheel, Role Play, Business } \\
\text { Wargaming, Synectics, Speculative Writing, Visualization, Metaphors, Assumption Reversal }\end{array}$ \\
\hline Prescriptive & $\begin{array}{l}\text { Relevance Trees, Morphological Analysis, Rich Pictures, Divergence Mapping, Coates and Jarratt, } \\
\text { Future Mapping, Backcasting, SRI Matrix, Science Fiction Analysis, Incasting, Genius Forecasting, } \\
\text { Futures Biographies, TRIZ, Future History, Alternative History }\end{array}$ \\
\hline Multicriterial & $\begin{array}{l}\text { Key Technologies, Source Data Analysis, Migration Anal., Shift-Share Anal., DEA, Factor Anal., } \\
\text { Correspondence Anal., Cluster Analysis, Sensitivity Analysis, AHP, Input-Output Analysis, Priorization, } \\
\text { SMART, PRIME, MCDM }\end{array}$ \\
\hline Radar & $\begin{array}{l}\text { Scientometrics, Webometrics, Patent Analysis, Bibliometrics, Technological Substitution, S-Curve } \\
\text { Analysis Technology Mapping, Analogies }\end{array}$ \\
\hline Simulation & $\begin{array}{l}\text { Probability Trees, Trend Extrapolation, Long Wave Analysis, Indicators, Stochastic Forecast, } \\
\text { Classification Trees, Modeling and Simulation, System Dynamics, Agent Modeling }\end{array}$ \\
\hline Diagnostic & $\begin{array}{l}\text { Object Simulation, Force Field Analysis, Word Diamond, SWOT, STEEPVL, Institutional Analysis, } \\
\text { DEGEST, Trial\&Error, Requirement Analysis, Theory of Constraint, Issue Management, ANKOT }\end{array}$ \\
\hline Analytical & $\begin{array}{l}\text { SOFI, Stakeholder Analysis, Cross-Impact Analysis, Trend Impact Analysis, Structural Analysis, } \\
\text { Megatrend Analysis, Critical Influence Analysis, Technology Barometer, Cost-Benefit Analysis, } \\
\text { Technology Scouting, Technology Watch, Sustainability Analysis, Environmental Scanning, Content } \\
\text { Analysis, FMEA, Risk Analysis, Benchmarking }\end{array}$ \\
\hline Survey & $\begin{array}{l}\text { Web Research, Desk Research, Technology Assessment, Social Network Analysis, Literature Review, } \\
\text { Retrospective Analysis, Macrohistory, Back-View Mirror Analysis }\end{array}$ \\
\hline Strategic & $\begin{array}{l}\text { Technology Roadmapping, Technology Positioning, Delphi, Scenarios, Social Impact Assessment, } \\
\text { RPM, Technological Scanning, Multiple Perspectives Assessment, Causal Layered Analysis, MANOA, } \\
\text { Action Learning }\end{array}$ \\
\hline
\end{tabular}

Source: (Magruk, 2011).

sources of information, by which identification and analysis of uncertainty areas are fuller, and minimization can be done in a manner based on the expert experience.

The second class has a strong connection with research of uncertainty. The methods of this group enable both synthetic and unconventional presentation of many issues with a single shot (in the form of a diagram, map, picture). These methods facilitate the discovery (using simulations, analogies) of seemingly unrelated relationship (interaction) between different objects, influencing the formation of entirely new ideas. The creative class allows the analysis and minimization of the effects of uncertainty in an unconventional (for instance avantgarde) way.

Using the prescriptive methods, it is possible to undertake identification, indexing and counting of solutions to the problem utterly from the point of view of present and future
Tab. 3. Linking classes of foresight methods with the research areas of uncertainty: the identification, analysis, and minimization

\begin{tabular}{|c|c|c|c|c|}
\hline & \multicolumn{3}{|c|}{ RESEARCH OF UNCERTAINTY } \\
\hline & & IDENTYFICATION & ANALYSIS & MINIMALIZATION \\
\hline \multirow{10}{*}{ 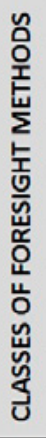 } & CONSULTATIVE & *** & *** & * * \\
\hline & CREATIVE & ** & *** * & 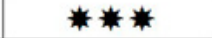 \\
\hline & PRESCRIPTIVE & ** & 萧 & 苇茦 \\
\hline & MULTICRITERIAL & 萧萧 & 半米米 & * * \\
\hline & RADAR & *** & ** & * \\
\hline & SIMULATION & 样 & * * * & * * \\
\hline & DIAGNOSTIC & ** & *** & ** \\
\hline & ANALYTICAL & * * & 兼兼 & 兼 \\
\hline & SURVEY & * * * * & * * & * \\
\hline & STRATEGIC & 萧 & ** & 㭗㭗 \\
\hline \multirow{3}{*}{ 㭗 } & \multirow{3}{*}{\multicolumn{3}{|c|}{$\begin{array}{l}\text { the degree of linkage between methods of the } \\
\text { classes with the possibility of study into one of three } \\
\text { areas of uncertainty research }\end{array}$}} & * low or zero \\
\hline & & & & * * medium \\
\hline & & & & **** \\
\hline
\end{tabular}

actions, events, activities, in different dimensions. The overall analysis of the future can better influence the minimization of the effect of uncertainty than in the case of methods that recognize the reality in a piecemeal.

The fourth class of multicriterial methods uses quantitative and qualitative data for complex research problems. These methods help in the classification and selection of alternative actions, with a large 
number of decision-making criteria. They are used to determine the optimal priority issues. Therefore, methods of this group have a strong potential to identify and analyse areas of uncertainty.

Most methods of the radar class refer to an analysis of the current and past so that these methods can be checked in the identification of the various aspects of uncertainty. They focus on monitoring, categorization, typology, classification, identification of networks, analysis of the influence analysis of various sources in order to detect important signals regarding the latest research discoveries, technological innovation and any potential opportunities and threats.

The simulation class focuses on hard (quantitative) methods of mathematical perspective. The most characteristic features of this cluster are analyticity, back to work in a virtual environment, the nature of graphic, using secondary data, generate codified results. Thanks to the methods of this group, it is possible to measure the numerical level of uncertainty in extreme cases, receiving the form of the risk.

The purpose of the methods belonging to the diagnostic class is a systemic recognition, analysis and assessment of the current state of the object as well as the quality-strategic identification, assessment, and management of potential problems, constraints and associated uncertainty, among other solutions from other systems using objects.

Analytical methods allow defining a long-term assessment of developments in selected areas, indicating their intensity and level. These methods allow identifying the breakthrough phenomenon (e.g. technology) products, potential strategies, legal regulations related to the examined areas, as well as solutions to specific problems. In the context of uncertainty research, the analytical methods are characterized by similar characteristics of the diagnostic class.

Methods of the survey group, in the context of uncertainty research, have a similar interpretation to the radar methods. They assist in the evaluation of available secondary data, such as publications, reports, newsletters, databases, directories, statistics, etc. The survey class is characterised by reflective, logical approach, based on the analysis of the current state of knowledge regarding the study area (both in the strictly scientific way, as well as based on simple observations).

The methods of the strategic class are helpful in planning, scenario building, solving the complex problems of decision-making and change management, strongly taking into account the conditions of uncertainty. They assist in the formulation of the final results of the final projects while discovering the key factors and developing trends in the context of science, innovation, and technology.

Referring to the above analysis, it is clear that classes of foresight methods have the strongest relationship with the areas of identification and analysis of uncertainty. The strongest relationship for minimizing the phenomenon of uncertainty refers to the creative, prescriptive, and strategic classes.

\section{CONCLUSIONS}

The logic of human behaviour involves actual indefiniteness, real change, and the lack of continuity. The formation of a future situation affects a vast number of variables, among which occur those partially or completely undefined (Samecki, 1967).

In a number of future events, there is a lack of statistical repeatability as well as it is difficult to speak about the possibility of using deterministic models.

Foresight is one of the significant scientific considerations for the future that take into account the conditions of uncertainty and treat research object (country, region, company, society, etc.) in a systematic way. Despite several decades of foresight presence in the field of science, it still requires unambiguous formulation, especially in terms of methodical knowledge, relating to the management of uncertainty.

It is believed that dealing with uncertainty is the main task of entities that take strategic decisions. This is due to the treatment of various organisations (countries, regions, enterprises) as social beings, in which uncertainty will decline provided steps are taken to rationalize the activities of these organisations (Łuczak, 2012). Such activities include undoubtedly the future operation of foresight.

Predicting the future regardless of the time horizon, it is always associated with some degree of uncertainty. The greater and more complex areas of reality are examined (Samuelson \& Marks, 1998).

At present, we have a number of definition of uncertainty. Analysis of this phenomenon in the context of the future of complex reality can use theoretical assumptions of the indeterminacy principle by Heisenberg. We can say that the uncertainty lies in the fact that the observer of the tested system at a given time and place, is not be able to determine the further functioning of this system with complete certainty (Zawiła-Niedźwiecki, 2007).

According to the author, the goal established in the article has been achieved. Relationships of sys- 
temic research of foresight to research of the uncertainty phenomenon were identified and analysed. The author characterized the classes of foresight methods, by which it is possible to switch off their relationship to the process of testing the uncertainty using three aspects: identification, analysis, and minimizing. In addition, the rationality of the system's anticipation of the future was demonstrated in order to make appropriate practical decisions assuming occurrence of uncertainty regarding the behaviour of systems at the same time accepting the non-deterministic perception and the understanding of reality.

\section{ACKNOWLEDGEMENTS}

The research was conducted within S/WZ/1/2014 project and was financed from Ministry of Science and Higher Education funds.

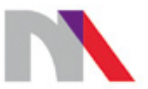

\section{Ministry of Science and Higher Education}

Republic of Poland

7th International Conference on Engineering, Project, and Production Management (EPPM2016) was financed in the framework of the contract no. 712/P-DUN/2016 by the Ministry of Science and Higher Education from the funds earmarked for the public understanding of science initiatives.

7th International Conference on Engineering, Project, and Production Management (EPPM2016) finansowana w ramach umowy 712/P-DUN/2016 ze środków Ministra Nauki i Szkolnictwa Wyższego przeznaczonych na działalność upowszechniającą naukę.

\section{LITERATURE}

Błajet, P. (2011). Foresight w edukacji, czyli jak przyszłość określa teraźniejszość [Foresight in education - how future determines the present?]. Teraźniejszość Człowiek - Edukacja, 2(54), 33-45.

Bojarski, W. (1981). Zagadnienia nieokreśloności wielkich systemów i niepewności [Indeterminacy issues of great systems and uncertainties]. In W. Bojarski (Ed.). Metody modelowania i optymalizacji systemów energetycznych $w$ warunkach niepewności [Modeling and optimization methods of energy systems in conditions of uncertainty], (pp. 7-28). Wrocław, Poland: PAN, Ossolineum.

Bubner, N., Bubner, N., Helbig, R., \& Jeske, M. (2014). Logistics trend radar, Delivering insight today. Creating value tomorrow!. Troisdorf: Pub. DHL Customer Solutions \& Innovation.

Cempel, C. (2005). Teoria $i$ inżynieria systemów - zasady $i$ zastosowania myślenia systemowego [Theory and systems engineering - principles and applications of systems thinking]. E-script of Zakład Wibroakustyki i Bio-Dynamiki Systemów Politechniki Poznańskiej. Retrived from http://neur.am.put.poznan.pl

Courtney, H. (2001). 20/20 Foresight: crafting strategy in an uncertain world. Boston, Massachusetts: Harvard Business Press.

Courtney, H., Kirkland, J., \& Viguerie, P. (1997). Strategy Under Uncertainty. Harvard Busienss Review, 75(6), 67-79.

Dziel, E. (2011). Niepewność i ryzyko w działalności gospodarczej. Periodyk Naukowy Akademii Polonijnej, 1(5), 135-144.

Fatyga, B. (Ed.). (2015). Praktyki Badawcze [Research practices]. Warszawa: Instytut Stosowanych Nauk Społecznych UW.

Graf, H. G. (1999). Prognosen und Szenarien in der Wirtschaftspraxis [Forecasts and scenarios in economic practice]. Munchen: Carl Hanser Verlag.

Gudanowska, A. E. (2014). Technology mapping as a method of technology analysis in the light of selected foreign experiences. Ekonomia i Zarządzanie, 6(1), 265-281.

Gudanowska, A. E. (2016). Technology mapping - proposal of a method of technology analysis in foresight studies. Business: Theory and Practice, 17(3), 243-250.

Halicka, K. (2014). Designing routes of development of renewable energy technologies. Procedia - Social and Behavioral Sciences, 156, 58-62.

Halicka, K. (2016). Innovative Classification of Methods of The Future-Oriented Technology Analysis. Technological and Economic Development of Economy, 22(4), 574-597.

Hawking, S. W. (1990). Krótka historia czasu. Od wielkiego wybuchu do czarnych dziur [A Brief Story of Time from the Big Bang to Black Holes]. Poznań, Poland: Wyd. Zysk i S-ka.

Heller, M. (2016a). Filozofia kosmologii [The philosophy of cosmology]. Kraków, Poland: Coperncus Center Press.

Heller, M. (2016b). Filozofia przypadku [The philosophy of fortuity]. Kraków, Poland: Coperncus Center Press.

Janasz, K. (2009). Ryzyko i niepewność w gospodarce wybrane aspekty teoretyczne. Studia i Prace Wydziału Nauk Ekonomicznych i Zarządzania, 14, 87-98.

Jańczuk, E. A. (2007). Identyfikacja kierunków rozwoju $w$ procesie foresight [Identification of development directions in the process of foresight]. Białystok, Poland: unpublished MA thesis, written under the direction of J. Nazarko, Politechnika Białostocka, Wydział Zarządzania.

Kononiuk, A., \& Nazarko, J. (2014). Scenariusze w antycypowaniu i kształtowaniu przyszłości [Scenarios in anticipating and shaping the future]. Warszawa, Poland: Oficyna a Wolters Kluwer business.

Łuczak, J. (2012). Pewność, niepewność i ryzyko w decyzjach menedżerskich. Zarzadzanie i Finanse, 10(1/1), 77-89.

Magnus, S. (2012). The Adventure Future. Retrived from https://adventurefuture.wordpress.com

Magruk, A. (2011). Innovative classification of technology foresight methods. Technological and Economic Development of Economy, 17(4), 700-716. 
Olszewska, A. M., \& Gudanowska, A. E. (2011). Zarządzanie wiedzą a innowacyjność. Economy and Management, 3(4), 159-168.

Ringland, G. (1998). Scenario Planning: Managing for the Future. Chichester: John Wiley \& Sons.

Samecki, W. (1967). Ryzyko i niepewność $w$ działalności przedsiębiorstwa przemysłowego [Risks and uncertainty in the activity of an industrial enterprise]. Warszawa, Poland: Państwowe Wydawnictwo Ekonomiczne.

Samuelson, W. F., \& Marks, S. G. (1998). Ekonomia menedżerska [Managerial economics]. Warszawa, Poland: PWE.

Saritas, O., \& Oner, M. A. (2004). Systemic analysis of UK foresight results Joint application of integrated management model and roadmapping. Technological Forecasting \& Social Change, 71(1), 27-65.

Voros, J. (2003). A generic foresight process framework. Foresight, 5(3), 10-21.

Zawiła-Niedźwiecki, J. (2007). Niepewność w Zarządzaniu. Zeszyty Naukowe. Prace Instytutu Ekonomiki i Organizacji Przedsiębiorstw, Uniwersytet Szczeciński, 50(1), 253-259. 